\title{
Purification and Properties of $\varepsilon$-Caprolactone Hydrolases from Acinetobacter NCIB 9871 and Nocardia globerula CL1
}

\author{
By ANDREW P. BENNETT, ELISABETH J. STRANG, \\ PETER W. TRUDGILL* AND VIVIAN T. K. WONG \\ Department of Biochemistry, University College of Wales, Aberystwyth SY22 3DD, UK
}

(Received 25 June 1987; revised 14 August 1987)

The $\varepsilon$-caprolactone hydrolases (EC 3.1.1-) induced by growth of Acinetobacter NCIB 9871 and Nocardia globerula CLl with cyclohexanol were purified to homogeneity. Both enzymes constituted approximately $1 \%$ of the soluble protein of the bacteria. Each was formed from two electrophoretically indistinguishable subunits and each had a closely similar $\boldsymbol{M}_{\mathrm{r}}$ value $(\simeq 60000)$. Both enzymes had high turnover numbers typical of carboxyesterases, broad $\mathrm{pH}-$ activity spectra and very restricted substrate specificities. In contrast to other bacterial lactone hydrolases they catalysed irreversible lactone hydrolysis and were not inhibited by thiol-reactive compounds. Their sensitivity to Paraoxon (diethyl $p$-nitrophenylphosphate) suggested that they, in common with mammalian acetylcholinesterase and carboxyesterases, have a functional catalytic centre serine.

\section{INTRODUCTION}

The bacterial oxidation of simple alicyclic hydrocarbons, alcohols and ketones by organisms capable of utilizing them as sole carbon sources necessitates cleavage of the carbocyclic ring (Trudgill, 1984). With few exceptions (Yugari, 1961; Murray et al., 1974), the ring fission substrate (a lactone) is formed by a monooxygenase-mediated insertion of oxygen into a cyclic ketone (Norris \& Trudgill, 1971; Griffin \& Trudgill, 1972, 1976; Donoghue \& Trudgill, 1975; Davey \& Trudgill, 1977). Although some of the lactones thus formed are unstable and cleave spontaneously (Davey \& Trudgill, 1977), the majority are hydrolysed by induced lactone hydrolases with the formation of the corresponding hydroxy acids. The monooxygenases that form the ring fission substrates from the cyclic ketones have been purified from a number of organisms (Donoghue et al., 1976; Griffin \& Trudgill, 1976) and have been shown to mimic the peracid-mediated Baeyer-Villiger reaction (Baeyer \& Villiger, 1899; Ryerson et al., 1982). In contrast, the ring-cleaving lactone hydrolases have been little studied.

Although only a limited number of lactone hydrolases from other bacteria and animal sources have been studied, they fall into two recognizable groups, which have either a sensitivity towards thiol-reactive inhibitors (Kersten et al., 1982; Maruyama, 1983) or a divalent cation requirement for activity (Fishbein \& Bessman, 1966a,b). This paper reports the purification, structure and kinetic properties of the $\varepsilon$-caprolactone hydrolases ( $\varepsilon$-caprolactonases EC 3.1.1-) from cyclohexanol-grown Acinetobacter NCIB 9871 and Nocardia globerula CLl.

\section{METHODS}

Bacterial strains and culture conditions. $N$. globerula CL1 was isolated from woodland soil by elective culture with cyclohexanol as sole carbon source (Norris \& Trudgill, 1971); Acinetobacter NCIB 9871 was a gift from Dr P. J. Chapman, University of Minnesota, St Paul, Minn., USA. Stock cultures were grown on nutrient agar (Oxoid) at $30^{\circ} \mathrm{C}$, stored at $3{ }^{\circ} \mathrm{C}$ and subcultured at regular intervals.

Abbreviations: Azodrin, 3-hydroxy- $N$-methylcrotonamide dimethylphosphate; Paraoxon, diethyl $p$-nitrophenylphosphate; FPLC, fast protein liquid chromatography. 
Cells were grown at $30^{\circ} \mathrm{C}$ in a medium that contained $\left(\mathrm{g} \mathrm{l}^{-1}\right): \mathrm{KH}_{2} \mathrm{PO}_{4}, 2 ; \mathrm{Na}_{2} \mathrm{HPO}_{4}, 4 ;\left(\mathrm{NH}_{4}\right)_{2} \mathrm{SO}_{4}, 2$. Traceelement solution (Rosenberger \& Elsden, 1960) was added at $0.4 \%(\mathrm{v} / \mathrm{v})$ before the medium was sterilized by autoclaving. Cyclohexanol was supplied either from vapour infusion tubes (Claus \& Walker, 1964) or by direct addition, and large batches of cells were grown and harvested according to the regime previously described by Donoghue et al. (1976).

Preparation of cell extracts. Washed cells, resuspended in $1.5 \times$ cell vol. $42 \mathrm{mM}-\mathrm{KH}_{2} \mathrm{PO}_{4} / \mathrm{Na}_{2} \mathrm{HPO}_{4}$ buffer (pH 7.1) were disrupted by passage through a French pressure cell with a pressure difference at the orifice of $138 \mathrm{MPa}$. Unbroken cells and cell debris were removed by centrifugation at $25000 \mathrm{~g}$ and $3{ }^{\circ} \mathrm{C}$ for $30 \mathrm{~min}$. The crude cell extracts typically contained $25-30 \mathrm{mg}$ protein $\mathrm{ml}^{-1}$ and were stored at $-20^{\circ} \mathrm{C}$ until required.

Protein measurement. The biuret assay as modified by Gornall et al. (1949) was used for the estimation of protein in concentrated solution. A crude estimate of the protein content of column fractions was made by measuring absorbance at $280 \mathrm{~nm}$. For accurate measurement of the protein content of pooled column fractions and final enzyme preparations the biuret assay or the tannin-gum-arabic procedure (Mejbaum-Katzenellenbogen \& Dobryszcka, 1959) was used depending upon the amount of material available.

Enzyme assay. $\varepsilon$-Caprolactone hydrolase ( $\varepsilon$-caprolactonase) was assayed by three alternative procedures. For all assays the enzyme unit is expressed by $\mu \mathrm{mol}$ substrate consumed or product formed $\mathrm{min}^{-1}$. (1) Accurate measurement of the $\varepsilon$-caprolactonase activity of cell extracts, pooled column fractions and pure enzymes was made by following the disappearance of the lactone. In a typical assay $100 \mu \mathrm{mol} \varepsilon$-caprolactone in $10 \mathrm{ml} 42 \mathrm{mM}$ $\mathrm{KH}_{2} \mathrm{PO}_{4} / \mathrm{Na}_{2} \mathrm{HPO}_{4}$ buffer $(\mathrm{pH} 7 \cdot 1)$ was preincubated at $30^{\circ} \mathrm{C}$ on a metabolic shaker. Following the addition of the enzyme fraction (2-5 units) samples $(1 \mathrm{ml})$ were removed at timed intervals and residual lactone measured by the procedure of Cain (1961).

(2) Lactone hydrolase activity of column fractions was measured by a rapid semiquantitative procedure dependent upon the $\mathrm{pH}$ change resulting from hydrolysis of $\varepsilon$-caprolactone to 6-hydroxyhexanoic acid in weakly buffered solution. A typical assay mixture contained, in $3 \mathrm{ml}: 1 \mu \mathrm{mol} \mathrm{KH_{2 }} \mathrm{PO}_{4} / \mathrm{Na}_{2} \mathrm{HPO}_{4}$ buffer (pH 7.1), $50 \mu \mathrm{g}$ bromothymol blue indicator and enzyme (0.2-0.5 units). Reactions at $30^{\circ} \mathrm{C}$ were initiated by the addition of $2 \mu \mathrm{mol} \varepsilon$-caprolactone (aqueous solution) and acid production was followed by measuring the change in absorbance at $610 \mathrm{~nm}$. The assay system was routinely calibrated by measuring the total absorbance change observed following the addition of limited $(0 \cdot 2-1 \cdot 0 \mu \mathrm{mol})$ amounts of $\varepsilon$-caprolactone. An absorbance change of $0 \cdot 1$ corresponded to the production of approximately $0.15 \mu \mathrm{mol}$ of acid from the lactone. Rapid preliminary screening of column fractions was achieved by adding $1-10 \mu$ lof each fraction to a separate well of an immunotest well tray containing $0.2 \mathrm{ml}$ of a solution containing buffer, indicator and substrate at the concentrations used in the spectrophotometric assay. Visual observation of a colour change from blue/green to yellow indicated the location of the $\varepsilon$-caprolactonase.

(3) For studies with substrate analogues, and of the effects of putative inhibitors, reactions with pure enzymes were followed in an autotitrator (Pye-Unicam). In a typical assay the formation of acid was followed by monitoring the controlled addition of $2-5 \mathrm{~mm}-\mathrm{NaOH}$ to a stirred reaction vessel that contained, in an initial volume of $10 \mathrm{ml}$ distilled water adjusted to the required starting $\mathrm{pH}, 0.5-2$ units of enzyme. The endogenous rate of $\mathrm{NaOH}$ addition required to maintain the desired reaction $\mathrm{pH}$ was followed for several minutes. An aqueous solution of the substrate $(10-20 \mu \mathrm{mol})$ was then added and the rate of reaction-stimulated $\mathrm{NaOH}$ addition measured. For studies of the lactonization of hydroxyacids the burette contained $4 \mathrm{mM}-\mathrm{HCl}$.

Enzyme purification. All procedures with the exception of fast protein liquid chromatography (FPLC), which was done at room temperature, were done at $2-4{ }^{\circ} \mathrm{C}$. $\varepsilon$-Caprolactonase from Acinetobacter NCIB 9871 . Step 1. Cell extract, prepared from approximately $100 \mathrm{~g}$ cyclohexanol-grown Acinetobacter NCIB 9871 resuspended in $42 \mathrm{mM}$ $\mathrm{KH}_{2} \mathrm{PO}_{4} / \mathrm{Na}_{2} \mathrm{HPO}_{4}$ buffer ( $\mathrm{pH} 7 \cdot 1$ ), was treated with saturated $\left(\mathrm{NH}_{4}\right)_{2} \mathrm{SO}_{4}$ to bring it to $0 \cdot 4$ saturation. After stirring at $4{ }^{\circ} \mathrm{C}$ for $30 \mathrm{~min}$ the precipitate was removed by centrifugation at $25000 \mathrm{~g}$ and discarded. The supernatant was then brought to 0.55 saturation and again stirred and centrifuged. The pellet was dissolved in $40 \mathrm{ml} 42 \mathrm{mM}-\mathrm{KH}_{2} \mathrm{PO}_{4} / \mathrm{Na}_{2} \mathrm{HPO}_{4}$ buffer $(\mathrm{pH} 7 \cdot 1)$ and dialysed overnight against two changes (each of $5 \mathrm{l}$ ) of the same buffer.

Step 2. The dialysed solution was applied to a DEAE-cellulose column $(2.5 \times 10 \mathrm{~cm})$ equilibrated with the same buffer. The column was washed with buffer $(100 \mathrm{ml})$ and a linear $\mathrm{KCl}$ gradient $(500 \mathrm{ml}, 0-0.5 \mathrm{M}-\mathrm{KCl}$ in phosphate buffer) was applied to elute the hydrolase. Fractions $(6 \mathrm{ml})$ were collected and those containing hydrolase activity, typically fractions $40-45$, were pooled.

Step 3. The pooled fractions were concentrated to a volume of $<10 \mathrm{ml}$ by use of an Amicon ultrafiltration cell fitted with a PM10 membrane, and dialysed against two changes of $0.1 \mathrm{M}$-Tris/HCl buffer (pH 8.0$)$ for a total of $8 \mathrm{~h}$.

Step 4. The concentrate from step 3 was loaded onto a column of Sephacryl S-200 $(2.5 \times 80 \mathrm{~cm})$ and the column eluted with $0 \cdot 1 \mathrm{M}$-Tris $/ \mathrm{HCl}$ buffer $(\mathrm{pH} 8.0)$ under gravity feed. Fractions $(10 \mathrm{ml})$ were collected and those containing the enzyme (fractions 27 and 28 ) were pooled.

Step 5. The pooled fractions from the Sephacryl S- 200 column were concentrated using the ultrafiltration cell (Amicon). 
Step 6. The concentrated material was passed through a cellulose acetate membrane filter $(0 \cdot 22 \mu \mathrm{m}$ pore diameter) and 10-20 mg samples were subjected to FPLC on a Polyanion 17 column (Pharmacia), which was developed with an uninterrupted gradient from $0-1 \mathrm{M}-\mathrm{KCl}$ in $20 \mathrm{mM}$-Tris/ $\mathrm{HCl}$ buffer $(\mathrm{pH} 8 \cdot 0$ ). Fractions containing $\varepsilon$-caprolactonase were pooled, concentrated as described above and $1-2 \mathrm{mg}$ samples again subjected to FPLC on a Mono Q column (Pharmacia), which was developed with an uninterrupted gradient from 0 to $0.75 \mathrm{M}$ $\mathrm{KCl}$. The single accumulated fraction that contained the $\varepsilon$-caprolactonase activity was stored at $-20^{\circ} \mathrm{C}$ until required.

$\varepsilon$-Caprolactonase from $N$. globerula $C L 1$. This was purified by the same basic procedure as used for $\varepsilon$ caprolactonase from Acinetobacter NCIB 9871 with the following modifications: the 0.55-0.75 $\left(\mathrm{NH}_{4}\right)_{2} \mathrm{SO}_{4}$ fraction was retained; the DEAE-cellulose column was eluted with a 0.2 to $0.5 \mathrm{M}-\mathrm{KCl}$ gradient and fractions $45-50$ pooled; $6.5 \mathrm{ml}$ fractions were collected from the Sephacryl S-200 column and those of constant specific activity (fractions 31-34) were pooled; the pooled fractions from the Sephacryl S-200 column were concentrated by $\left(\mathrm{NH}_{4}\right)_{2} \mathrm{SO}_{4}$ precipitation ( 0.75 saturation) followed by centrifugation at $25000 \mathrm{~g}$ and $3{ }^{\circ} \mathrm{C}$ for $30 \mathrm{~min}$. The protein pellet was dissolved in 1-2 ml $42 \mathrm{mM}-\mathrm{KH}_{2} \mathrm{PO}_{4} / \mathrm{Na}_{2} \mathrm{HPO}_{4}$ buffer ( $\mathrm{pH} 7 \cdot 1$ ), dialysed overnight against the same buffer to remove $\left(\mathrm{NH}_{4}\right)_{2} \mathrm{SO}_{4}$ and stored at $-20^{\circ} \mathrm{C}$ until required.

$P A G E$. This was done under non-denaturing conditions using polyacrylamide gels ranging from 6 to $15 \%(\mathrm{w} / \mathrm{v})$ according to the procedure of Davies (1964) on $1.5 \mathrm{~cm}$-thick slab gels. Sodium dodecyl sulphate (SDS) slab gel electrophoresis was done according to the procedure of Weber \& Osborn (1975). The enzyme preparations $(0 \cdot 5-$ $1 \mathrm{mg} \mathrm{ml}{ }^{-1}$ ), in $10 \mathrm{~mm}-\mathrm{Na}_{2} \mathrm{HPO}_{4}$ buffer ( $\mathrm{pH} \mathrm{7.2)} \mathrm{containing} 1 \%(\mathrm{w} / \mathrm{v})$ SDS and $1 \%(\mathrm{w} / \mathrm{v}) 2$-mercaptoethanol, were boiled for $2 \mathrm{~min}$ and cooled on ice. Standard marker proteins were similarly treated. Samples of the marker proteins and the treated enzymes containing $20-40 \mu \mathrm{g}$ of each component were subjected to electrophoresis on $7.5 \%(\mathrm{w} / \mathrm{v})$ polyacrylamide gels together with bromophenol blue tracking dye. Electrophoresis of all gels was done until the tracking dye was $1-2 \mathrm{~cm}$ from the bottom of the gel. Gels were stained with $0 \cdot 2 \%(\mathrm{w} / \mathrm{v})$ Coomassie Brilliant Blue $\mathrm{R} 250$ in $\mathrm{C}_{2} \mathrm{H}_{5} \mathrm{OH} / \mathrm{H}_{2} \mathrm{O} / \mathrm{CH}_{3} \mathrm{COOH}(9: 9: 2$, by vol.) for several hours and destained in $\mathrm{H}_{2} \mathrm{O} / \mathrm{C}_{2} \mathrm{H}_{5} \mathrm{OH} / \mathrm{CH}_{3} \mathrm{COOH}(13: 5: 2$, by vol.).

$M_{\mathrm{r}}$ determination. The $M_{\mathrm{r}}$ values of the native $\varepsilon$-caprolactonases were determined in the ultracentrifuge by the method of Yphantis (1964). A double sector cell was used with the enzyme solution in one compartment and the diffusate, $42 \mathrm{mM}-\mathrm{KH}_{2} \mathrm{PO}_{4} / \mathrm{Na}_{2} \mathrm{HPO}_{4}$ buffer $(\mathrm{pH} 7 \cdot 1)$, in the other. For the enzyme from Acinetobacter $\mathrm{NCIB} 9871$ the rotor speed was 30000 r.p.m. and the initial protein concentration $0.4 \mathrm{mg} \mathrm{ml}^{-1}$; for the $N$. globerula enzyme the rotor speed was 35600 r.p.m. and the protein concentration $0.5 \mathrm{mg} \mathrm{m}^{-1}$. Both enzymes were stable for the duration of the experiment $(24 \mathrm{~h})$.

Gel filtration of the $\varepsilon$-caprolactonase from Acinetobacter NCIB 9871 was done on a calibrated column of Sephacryl S-200 $(2.5 \times 76 \mathrm{~cm})$ eluted with $0.1 \mathrm{M}$-Tris/HCl buffer $(\mathrm{pH} 8)$ by downward flow. The void volume was measured using Blue Dextran 2000 and the column was calibrated with the following protein $M_{\mathrm{r}}$ standards: cytochrome $c$ (12400); ovalbumin (43000); malate dehydrogenase (62000); $p$-cresol methylhydroxylase (114000); lactate dehydrogenase (140000); alcohol dehydrogenase (150000); fumarase (200000).

Chemicals. Cyclohexanol, $\varepsilon$-caprolactone, ethyl 2-cyclohexanonecarboxylate and the valerolactones were supplied by Aldrich. Alcohol dehydrogenase (EC 1.1.1.1), cytochrome $c$ and malate dehydrogenase (EC 1.1.1.37) were supplied by Boehringer-Mannheim. Sephacryl S-200 was obtained from Pharmacia. $\gamma$ butyrolactone was from Ralph Emanuel. Coomassie Brilliant Blue R250, fumarase (EC 4.2.1.2), 5,5'-dithiobis(2nitrobenzoate), $p$-hydroxymercuribenzoate, ovalbumin and SDS were from Sigma. DEAE-cellulose (DE52) was supplied by Whatman. 6-Hydroxyhexanoic acid and 4-hydroxyvaleric acid were prepared by the alkaline hydrolysis of $\varepsilon$-caprolactone and $\gamma$-valerolactone respectively according to the procedure previously described (Donoghue \& Trudgill, 1975). All other reagents were of high purity, the majority being of 'AnalaR' grade from BDH. Azodrin (3-hydroxy- $N$-methylcrotonamide) and Paraoxon (diethyl $p$-nitrophenylphosphate) were generous gifts from Dr R. E. Cripps of Shell Research, Sittingbourne, Kent; p-cresol methylhydroxylase was kindly supplied by Dr D. J. Hopper, University College of Wales, Aberystwyth, UK.

\section{RESULTS}

\section{Purification of enzymes}

The final procedures adopted for the purification of the $\varepsilon$-caprolactonase from Acinetobacter NCIB 9871 are shown as an example in Table 1. Both enzymes constituted about $1 \%$ of the soluble protein from induced cells. The enzyme from $N$. globerula CL1 was obtained in good yield $(\simeq 15 \%)$ with a specific activity of 1250 units $\mathrm{mg}$ protein ${ }^{-1}$ but greater difficulty was experienced in obtaining pure enzyme from Acinetobacter NCIB 9871 and, although the FPLC step provided homogeneous material, major losses were encountered. 


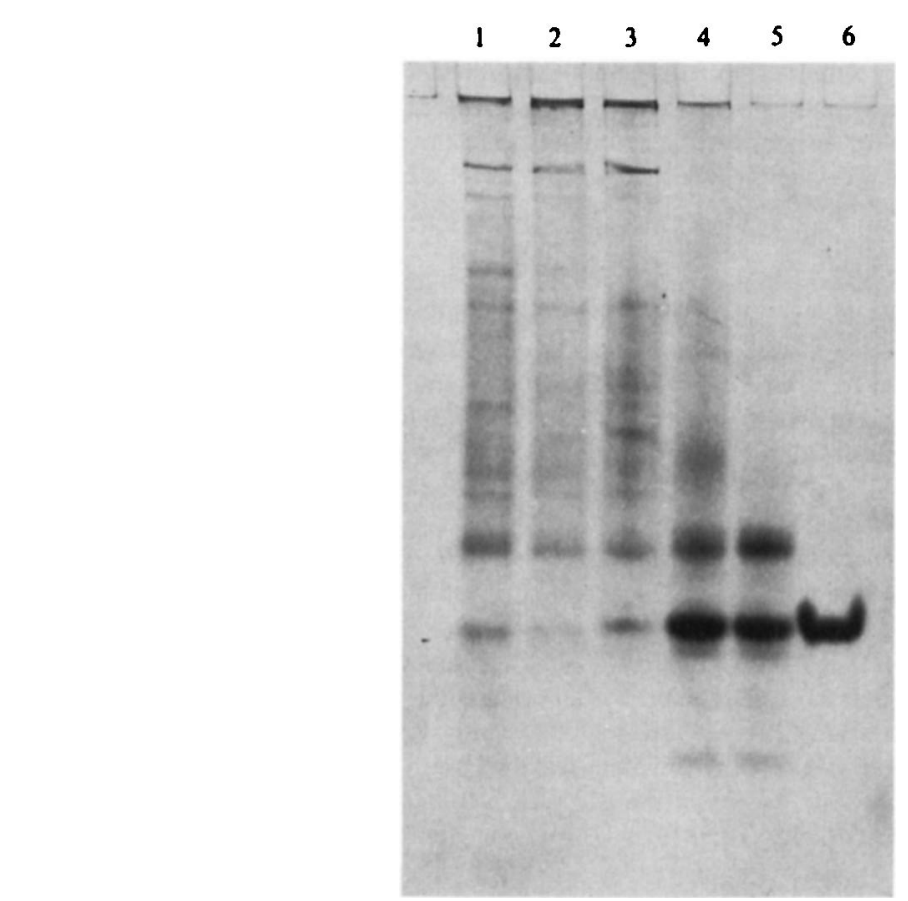

Fig. 1. PAGE $(10 \%, \mathrm{w} / \mathrm{v}$, acrylamide $)$ of fractions obtained in the purification of $\varepsilon$-caprolactonase from Acinetobacter NCIB 9871. Lane 1, crude extract; lane 2, $\left(\mathrm{NN}_{4}\right)_{2} \mathrm{SO}_{4}$ fraction; lane 3, DEAEcellulose pool; lanes 4 and 5, Sephacryl S-200 pool; lane 6, Mono Q fraction. Loadings were: lanes 1-5, $100 \mu \mathrm{g}$ protein; lane $6,20 \mu \mathrm{g}$ protein. Gels were stained with Coomassie Brilliant Blue R250.

Table 1. Purification of $\varepsilon$-caprolactonase from Acinetobacter NCIB 9871

\begin{tabular}{|c|c|c|c|c|}
\hline Stage & $\begin{array}{l}\text { Total } \\
\text { protein } \\
(\mathrm{mg})\end{array}$ & $\begin{array}{l}\text { Total } \\
\text { activity } \\
\text { (units) }\end{array}$ & $\begin{array}{c}\text { Specific activity } \\
{[\text { units (mg protein) })^{-1} \text { ] }}\end{array}$ & $\begin{array}{l}\text { Yield } \\
(\%)\end{array}$ \\
\hline ude extract & 2995 & 21000 & $7 \cdot 0$ & 100 \\
\hline $\left.\mathrm{NH}_{4}\right)_{2} \mathrm{SO}_{4}$ & 1046 & 22500 & $21 \cdot 5$ & 107 \\
\hline DEAE-cellulose chromatography & 26 & 6150 & 236 & 29 \\
\hline ephacryl S-200 chromatography & $9 \cdot 2$ & 3815 & 415 & 18 \\
\hline ast protein liquid chromatography & 0.97 & 650 & 670 & \\
\hline
\end{tabular}

\section{Properties of the enzymes}

Stability. Both enzymes were stable for several weeks at $-20{ }^{\circ} \mathrm{C}$ without significant loss of activity and did not require the addition of any protective agent.

Criteria of purity. Each enzyme gave a single significant stained protein band after electrophoresis under non-denaturing conditions on polyacrylamide gels that ranged from $6-$ $15 \%$ acrylamide. Fig. 1 shows the progressive purification of the Acinetobacter enzyme. Only very minor traces of impurities were detected by careful visual examination of gels of both purified enzymes.

$M_{\mathrm{r}}$ of enzymes and subunits. The $M_{\mathrm{r}}$ values of the two enzymes were determined to be 57000 (Acinetobacter) and 62000 ( N. globerula) by ultracentrifugal analysis from Yphantis plots. In addition, two independent gel-permeation runs on a Sephacryl S-200 column, calibrated with standard globular $M_{\mathrm{r}}$ markers, gave values of 67000 and 68000 for the Acinetobacter enzyme. Two independent SDS-PAGE runs showed single protein bands for both enzymes and subunit 
Table 2. Substrate specificities of the E-caprolactonases from Acinetobacter NCIB 9871 and N.globerula $C L I$

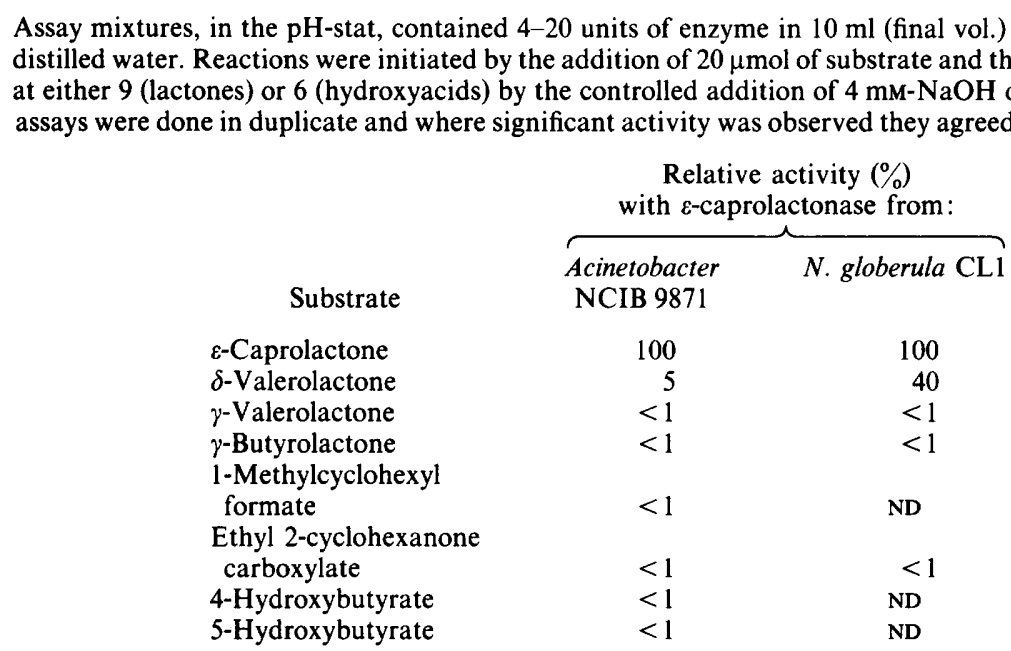

ND, Not determined.

$M_{\mathrm{r}}$ values of 29000 (Acinetobacter) and $31000(N$. globerula). The enzymes are therefore of similar $M_{\mathrm{r}}$ and each is formed from two electrophoretically identical subunits.

Absorption spectra. The absorption spectra of both enzymes showed only the absorbance due to aromatic amino acids with no distortions or additional absorbance indicative of the presence of non-protein prosthetic groups.

Substrate specificity and kinetic characteristics. The relative activities of the two hydrolases towards $\varepsilon$-caprolactone and a range of other lactones and esters is shown in Table 2. A high degree of specificity was observed, $\delta$-valerolactone being the only alternative substrate that was hydrolysed at a significant rate. Unfortunately, simple lactones of a ring size greater than that of $\varepsilon$-caprolactone were not available for testing.

When the enzymes were assayed in the $\mathrm{pH}$-stat at controlled $\mathrm{pH}$ values, ranging from 6 to 10.5 , maximum activity was observed in the $\mathrm{pH} 8-9$ region and the $\mathrm{pH}$-dependent change in activity was small $(<25 \%)$ over the $\mathrm{pH}$ range $7-10 \cdot 5$.

Lineweaver-Burk and Eadie-Hofstee treatments of results obtained when the $\varepsilon$ caprolactone concentration was varied, in duplicated unbuffered $\mathrm{pH}$-stat assays at $\mathrm{pH} 9$ with the enzyme from $N$. globerula $\mathrm{CLl}$, gave $K_{\mathrm{m}}$ values of $180 \mu \mathrm{M}$ and $160 \mu \mathrm{M}$ respectively and a turnover number [mol substrate hydrolysed (mol enzyme) $)^{-1} \mathrm{~min}^{-1}$ ] of $77000( \pm 7000)$. The $K_{\mathrm{m}}$ value for the Acinetobacter enzyme was too low $(<50 \mu \mathrm{M})$ to be measured by the relatively insensitive assay procedures available but in the presence of experimentally saturating levels of $\varepsilon$-caprolactone the turnover number was $45000( \pm 3600)$, derived from three determinations.

Reversibility of reaction. When reactions were allowed to run to completion in the $\mathrm{pH}$-stat with limited amounts $(16 \mu \mathrm{mol})$ of $\varepsilon$-caprolactone and the hydrolase from Acinetobacter NCIB 9871 an equimolar amount of $\mathrm{NaOH}$ was consumed over the reaction $\mathrm{pH}$ range 6-9.

Incubation of the hydrolase with chemically prepared 6-hydroxyhexanoate (Donoghue $\&$ Trudgill, 1975) at $\mathrm{pH} 6$ did not result in any observable change in $\mathrm{pH}$ that would have been indicative of formation of the lactone. $\gamma$-Valerolactone is not a substrate for hydrolysis (Table 1 ) and, in contrast to mammalian $\gamma$-lactone hydrolases, the $\varepsilon$-caprolactonase from Acinetobacter NCIB 9871 did not catalyse any detectable lactonization of 4-hydroxyvaleric acid.

Both the mammalian $\gamma$-lactone hydrolases (Fishbein \& Bessman, 1966a,b) and 2-pyrone-4,6dicarboxylic acid hydrolase from Pseudomonas spp. (Kersten et al., 1982; Maruyama, 1983) 
Table 3. Effects of various compounds on the activities of the $\varepsilon$-caprolactonases from Acinetobacter NCIB 9871 and N. globerula CLI

The standard pH-stat assay was used with a $10 \mathrm{ml}$ reaction volume and 1-2 units of enzyme. The reaction mixture, containing all components with the exception of the $\varepsilon$-caprolactone, was preincubated for $3 \mathrm{~min}$ at $\mathrm{pH} 8$ unless otherwise stated. Reactions were started by the addition of $20 \mu \mathrm{mol}$ of $\varepsilon^{-}$ caprolactone and reaction rates were compared with controls run under identical conditions. Where significant inhibition occurred assays were duplicated and agreed to within $\pm 11 \%$.

\begin{tabular}{|c|c|c|c|}
\hline \multirow[b]{2}{*}{ Compound } & \multirow[b]{2}{*}{$\begin{array}{c}\text { Final } \\
\text { concn } \\
(\mathrm{mM})\end{array}$} & \multicolumn{2}{|c|}{$\begin{array}{l}\text { Percentage inhibition of } \\
\text { enzyme from: }\end{array}$} \\
\hline & & $\begin{array}{c}\text { Acinetobacter } \\
\text { NCIB } 9871\end{array}$ & N. globerula CL1 \\
\hline 4-Chloromercuribenzoate & $0 \cdot 1$ & $<5$ & ND \\
\hline 5,5'-Dithiobis(2-nitrobenzoate) & $0 \cdot 1$ & $<5$ & ND \\
\hline Iodoacetate & 1 & $<5$ & 12 \\
\hline $2,2^{\prime}$-Dipyridyl & 1 & $<5$ & $<5$ \\
\hline Tiron & 10 & ND & $<5$ \\
\hline $\mathrm{Na}_{4}$-EDTA & 2 & $<5$ & ND \\
\hline $\mathrm{Na}_{4}$-EDTA & 5 & ND & 10 \\
\hline $\mathrm{Na}_{4}-\mathrm{EDTA}$ & 10 & $<5$ & ND \\
\hline 6-Hydroxyhexanoate & 2 & $<5$ & ND \\
\hline Azodrin & $0 \cdot 015$ & ND & 80 \\
\hline Paraoxon & 0.008 & 47 & ND \\
\hline Paraoxon & 0.015 & 88 & 91 \\
\hline Paraoxon & 0.03 & $>97$ & ND \\
\hline $\mathrm{CaCl}_{2}$ & 10 & $<5$ & ND \\
\hline $\mathrm{CaCl}_{2}^{*}$ & 1 & $<5$ & ND \\
\hline $\mathrm{CaCl}_{2}^{*}$ & 10 & $<5$ & ND \\
\hline $\mathrm{CoCl}_{2}, \mathrm{MgCl}_{2}$ or $\mathrm{MnCl}_{2}$ & 1 & $<5$ & ND \\
\hline
\end{tabular}

catalyse reversible lactone hydrolysis with $\mathrm{pH}$-dependent reaction equilibria and formation of the lactones being favoured below $\mathrm{pH} 8$.

\section{Inhibitor studies}

Azodrin and Paraoxon, both potent inhibitors of acetylcholine esterase, were the only putative inhibitors tested that had significant inhibitory action against the two hydrolases (Table 3). In contrast to observations made with 2-pyrone-4,6-dicarboxylate hydrolase (Kersten et al., 1982; Maruyama, 1983) there was no evidence for activity being dependent upon functioning thiol groups, nor was a requirement for $\mathrm{Ca}^{2+}$ or other divalent metal ions evident. In addition, those divalent cations tested were not inhibitory.

\section{DISCUSSION}

The $\varepsilon$-caprolactonases purified from members of the families Neisseriaceae (Acinetobacter NCIB 9871) and Nocardiaceae ( $N$. globerula CL1) have a common role in the oxidation of cyclohexanol by induced cells and are structurally similar. Each is constructed from two electrophoretically identical subunit polypeptides and both enzymes are of similar $M_{\mathrm{r}}$. In common with other investigated lactone hydrolases (Kersten et al., 1982; Maruyama, 1983) they contain no detectable prosthetic groups, have high turnover numbers and broad $\mathrm{pH}$-activity profiles.

The substrates hydrolysed by mammalian $\gamma$-lactonases most closely resemble, in structure, those used by the $\varepsilon$-caprolactonases from Acinetobacter and N. globerula, as they are structurally simple $\gamma$-lactones of 4-hydroxy monocarboxylic acids that range in chain length from four to eight carbon atoms. In contrast, 2-pyrone-4,6-dicarboxylic acid is a more complex lactone with 
two free carboxyl groups and two double bonds that constrain the ring structure. Both the $\gamma$ lactone hydrolases and 2-pyrone-4,6-dicarboxylic acid hydrolases catalyse reversible hydrolysis of their substrates in aqueous solution (Fishbein \& Bessman, 1966 b; Kersten et al., 1982; Maruyama, 1983). Enzymic formation of the lactones from the hydroxyacids under these conditions is a consequence of substrate structure. 4-Hydroxyacids form $\gamma$-lactones spontaneously in acid aqueous solution, there is little strain on the ring formed and $\Delta G$ is small. Although lactonization becomes less thermodynamically favourable as ring size increases the formation of 2-pyrone-4,6-dicarboxylate from 4-oxalmesaconate is favoured by the constraints imposed by the double bonds in the enol form of the acid. $\varepsilon$-Caprolactone does not form spontaneously from 6-hydroxyhexanoate in acidic solution and the $\varepsilon$-caprolactonase of Acinetobacter NCIB 9871 did not catalyse any detectable lactonization of this compound. Hydrolysis of $\varepsilon$-caprolactone was complete at all tested reaction $\mathrm{pH}$ values. Its failure to form the lactone from 4-hydroxyvaleric acid is a function of the very restricted substrate specificity (Table 1).

Attempts have been made to classify mammalian carboxylic esterases according to their behaviour towards organophosphates, in which class A enzymes utilize them as substrates, class B enzymes are inhibited by them and class $C$ enzymes are unaffected (Aldridge, 1953a, $b$; Krisch, 1971). Both $\varepsilon$-caprolactone hydrolases are inhibited by Paraoxon, fall into group B in the simple classification, and may be compared with the organophosphate-sensitive mammalian acetylcholine esterase (Froede \& Wilson, 1971) and carboxyesterases (Heymann et al., 1970, Krisch, 1971), which have a functional catalytic centre serine residue. It is interesting that they seem to have little in common with either (1) other bacterial lactone hydrolases that are inhibited by $1 \mathrm{mM} \mathrm{Co}{ }^{2+}, \mathrm{Cu}^{2+}, \mathrm{Mn}^{2+}$ or $\mathrm{Zn}^{2+}$ ions and thiol reactive reagents such as $p$ chloromercuribenzoate and 5,5'-dithiobis(2-nitrobenzoate) and are considered to have catalytically active thiol groups (Kersten et al., 1982, Maruyama, 1983), or (2) the $\mathrm{Ca}^{2+}$ dependent $\gamma$-lactonases of human blood and rat liver microsomes which are inhibited by sodium EDTA, $\mathrm{Mg}^{2+}$ and $\mathrm{Mn}^{2+}$ (Fishbein \& Bessman, 1966 b).

We wish to thank Dr R. E. Cripps of Shell Research for a generous gift of Paraoxon, Dr L. J. Rogers for performing the ultracentrifugal analyses and Juliet Trudgill for typing the manuscript.

\section{REFERENCES}

ALDRIDGE, W. N. (1953a). Serum esterases. 1. Two types of esterase ( $\mathrm{A}$ and $\mathrm{B}$ ) hydrolysing $p$-nitrophenyl acetate, propionate and butyrate and a method for their determination. Biochemical Journal 53, 110 117.

ALDRIDGE, W. N. (1953b). Serum esterases. 2. An enzyme hydrolysing diethyl $p$-nitrophenyl phosphate (E 600) and its identity with the $A$ esterase of mammalian sera. Biochemical Journal 53, 117-124.

BAEYer, A. \& VILLIGER, V. (1899). Einwerkung des caro'schen Reagens auf Ketone. Berichte der Deutschen Chemischen Gesellschaft 32, 3625-3633.

CAIN, R. B. (1961). The metabolism of protocatechuic acid by a Vibrio. Biochemical Journal 79, 298-312.

Claus, D. \& Walker, N. (1964). The decomposition of toluene by soil bacteria. Journal of General Microbiology 36, 107-122.

DAvies, B. J. (1964). Disc electrophoresis. II. Method and application to human serum proteins. Annals of the New York Academy of Sciences 121, 404-427.

Davey, J. F. \& Trudgill, P. W. (1977). The metabolism of trans-cyclohexan-1,2-diol by an Acinetobacter species. European Journal of Biochemistry 74, 115-127.

Donoghue, N. A. \& Trudgill, P. W. (1975). The metabolism of cyclohexanol by Acinetobacter
NCIB 9871. European Journal of Biochemistry 60, 17.

Donoghue, N. A., Norris, D. B. \& Trudgill, P. W. (1976). The purification and properties of cyclohexanone oxygenase from Nocardia globerula $\mathrm{CLl}$ and Acinetobacter NCIB 9871. European Journal of Biochemistry 63, 175-192.

Fishbein, W. N. \& Bessman, S. P. (1966a). Purification and properties of an enzyme in human blood and rat liver microsomes catalyzing the formation and hydrolysis of $\gamma$-lactones. I. Tissue localization, stoichiometry, specificity, distinct from esterase. Journal of Biological Chemistry 241, 4835-4841.

Fishbein, W. N. \& Bessman, S. P. (1966b). Purification and properties of an enzyme in human blood and rat liver microsomes catalyzing the formation and hydrolysis of $\gamma$-lactones. II. Metal ion effects, kinetics, and equilibria. Journal of Biological Chemistry 241, 4842-4847.

Froede, H. C. \& Wilson, I. B. (1971). Acetylcholinesterase. In The Enzymes, vol. 5, pp. 87-114. Edited by P. D. Boyer. New York: Academic Press.

Gornall, A. G., Bardawill, G. J. \& David, M. M. (1949). Determination of serum proteins by means of the biuret reaction. Journal of Biological Chemistry 177, 751-766. 
Griffin, M. \& Trudgill, P. W. (1972). The metabolism of cyclopentanol by Pseudomonas NCIB 9872. Biochemical Journal 129, 595-603.

Griffin, M. \& Trudgill, P. W. (1976). Purification and properties of cyclopentanone oxygenase from Pseudomonas NCIB 9872. European Journal of Biochemistry 63, 199-209.

Heymann, E., Krisch, K. \& Pahlich, E. (1970). Structure of the active center of microsomal carboxyesterase from pig kidney and liver. HoppeSeyler's Zeitschrift für physiologische Chemie 351, 931-942.

Kersten, P. J., Dagley, S., Whittaker, J. W., ARCIERO, D. M. \& LIPSCOMB, J. D. (1982). 2-Pyrone4,6-dicarboxylic acid, a catabolite of gallic acids in Pseudomonas species. Journal of Bacteriology 152, 1154-1162.

KRISCH, K. (1971). Carboxylic ester hydrolases. In The Enzymes, vol. 5, pp 43-69. Edited by P. D. Boyer. New York: Academic Press.

MaruYama, K. (1983). Purification and properties of 2-pyrine-4,6-dicarboxylate hydrolase. Journal of Biochemistry 93, 557-565.

Mejbaum-Katzenellenbogen, W. \& Dobryszcka, W. M. (1959). New method for quantitative determination of serum proteins separated by paper electrophoresis. Clinica chimica acta 4, 515-522.
Murray, J. R., Scheikowski, T. A. \& Macrae, I. C. (1974). Utilization of cyclohexanone and related substances by a Nocardia sp. Antonie van Leeuwenhoek 40, 17-24.

Norris, D. B. \& Trudgill, P. W. (1971). The metabolism of cyclohexanol by Nocardia globerula CL1. Biochemical Journal 121, 363-370.

Rosenberger, R. F. \& ELSDEN, S. R. (1960). The yields of Streptococcus faecalis grown in continuous culture. Journal of General Microbiology 22, 726-739.

Ryerson, C. C., Ballou, D. P. \& Walsh, C. (1982). Mechanistic studies on cyclohexanone oxygenase. Biochemistry 21, 2644-2655.

Trudgill, P. W. (1984). Degradation of the alicyclic ring. In Microbial Degradation of Organic Compounds, pp. 131-180. Edited by D. T. Gibson. New York: Marcel Dekker.

WEBER, K. \& OSBORN, M. (1975). Proteins and sodium dodecyl sulfate: molecular weight determination on polyacrylamide gels and related procedures. In The Proteins, vol. 1, pp. 179-223. Edited by H. Neurath \& R. L. Hill. Academic Press, New York.

YpHANTIS, D. A. (1964). Equilibrium ultracentrifugation of dilute solutions. Biochemistry 3, 297-317.

YUGARI, Y. (1961). Metabolism of cyclohexane-diol(1,2)-trans by a soil bacterium. Biken's Journal 4, 197-207. 